\title{
Edukasi Preventif Covid-19 Melalui Media Digital di Universitas Cenderawasih Papua
}

\author{
Yos Wandik ${ }^{1}$, Rif'iy Qomarrullah ${ }^{1}$, Kurdi ${ }^{1}$, I Putu Eka Wijaya Putra ${ }^{1}$, Lestari Wulandari $\mathrm{S}^{1}$, \\ Muh. Sawir ${ }^{2}$ \\ ${ }^{1}$ Universitas Cenderawasih, ${ }^{2}$ Universitas Yapis Papua \\ qomarrifqi77@gmail.com
}

Received: $1^{\text {st }}$ July $2020 \mid$ Accepted: $1^{\text {st }}$ December $2020 \mid$ Published: $30^{\text {th }}$ January 2021

\section{Key word:}

Preventive;

Covid-19;

digital media;

learning

\section{Kata Kunci}

Pelatihan; minyak telon; anti nyamuk; minyak essensial

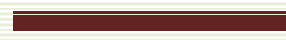

\section{Abstract}

Covid-19 preventive efforts were carried out in various ways and methods. One of them is using online digital media. The purpose of holding this activity is to find out what and how dangerous Covid 19 is with digital learning media. This activity uses a participatory method, using qualitative data and instruments. The science and technology targets in this activity are students of the Faculty of Sport Science (FIK), University of Cenderawasih Papua Indonesia in June 2020. The result of this service is that this activity is able to provide additional knowledge regarding the prevention and handling of Covid-19 and student enthusiasm because it is interactive. The Covid-19 Pandemic period had an impact, both positively and negatively. In terms of health, it is very detrimental, but for technological developments in the industrial era 4.0 this has an impact on the use of digital media facilities. Through the use of digital media, participants can understand and digest well that health promotion also needs attention. Furthermore, the benefits that can be obtained are the importance of maintaining a healthy lifestyle, maintaining cleanliness, and digital media that need to be used as much as possible in the era of technological disruption. Suggestions that can be given from this activity are: the community must adhere to health protocols and have awareness and willingness; healthy living.

\section{Abstrak}

Upaya preventif Covid-19 dilakukan dengan beragam cara dan metode. Salah satunya adalah memanfaatkan media digital online. Tujuan diadakannya kegiatan ini adalah mengetahui apa dan bagaimana bahaya Covid 19 dengan media pembelajaran digital. Kegiatan ini menggunakan metode partisipatif, dengan menggunakan data dan instrumen bersifat kualitatif. Sasaran Ipteks dalam kegiatan ini adalah mahasiswa Fakultas Ilmu Keolahragaan (FIK) Universitas Cenderawasih Papua Indonesia pada bulan Juni 2020. Hasil dari pengabdian ini adalah bahwa kegiatan ini mampu memberikan bekal tambahan pengetahuan terkait pencegahan dan penanganan Covid-19 dan antusiasme mahasiswa karena bersifat interaktif. Masa Pandemi Covid-19 meberikan dampak, baik secara positif maupun negatif. Secara kesehatan sangat merugikan, namun bagi perkembangan teknologi dalam era industri 4.0 hal ini berdampak pada penggunaan sarana media digital. Melalui pemanfaatan media digital tersebut dapat dipahami dan dicerna dengan baik oleh peserta bahwa promosi kesehatan juga perlu mendapatkan perhatian. Selanjutnya, manfaat yang dapat diperoleh yakni pentingnya menjaga perilaku hidup sehat, menjaga kebersihan, dan media digital perlu digunakan semaksimal 
mungkin di era disrupsi teknologi. Saran yang dapat diberikan dari kegiatan ini yakni: masyarkat harus taat protokol kesehatan dan memiliki kesadaran, dan kemauan; hidup sehat.

\section{PENDAHULUAN}

Dunia dengan segala kemajuannya membuat manusia tumbuh dengan bersanding pada teknologi (Arifin dan Nahar, 2017). Fenomena ini bukan lagi sesuatu yang dianggap tabu oleh manusia di-abad 21 (Juliannisa, 2020). Informasi pentingpun dapat diakses dengan begitu cepat dan massif, hal inilah kemudian membuat sebaran dampak penyakit berbahaya seperti yang terjadi pada akhir tahun 2019 di China dimana dunia dikejutkan dengan munculnya wabah corona virus (Covid-19).

Ratusan ribu orang kemudian terpapar, korban meninggal dan sembuh mencapai puluhan ribu (Yunus dan Rezki, 2020: 227). Tercatat belum genap enam bulan dari kemunculan pertamanya, virus ini telah memapar jutaan manusia diseluruh dunia. Peristiswa menarik sebagai rangkaian epidemik virus ini adalah kemudian terjadinya lockdown (karantina wilayah) (Lau, dkk, 2017). Kemudian, media digital memainkan peran yang sangat massif baik media mainstream maupun media sosial kontemporer (Pratiwi dan Nurhidayati, 2017).

Dampak sosial dan ekonomi menjadi penyerta utama yang menandai hancurnya sistem peradaban manusia modern. Sektor lain yang terdampak yaitu dunia pendidikan: dasar, menengah, dan pergutuan tinggi. Opsi yang dipilih kemudian adalah pembelajaran dan aktivitasnya dialihkan pada sektor privat (rumah pribadi) dengan bertumpu pada media belajar berbasis digital (Yuliana, 2020: 187).

Kampus dan sekolah di Indonesia selanjutnya mengadopsi sistem belajar berbasis Daring (dalam jaringan) (Dimyati A., dkk, 2017). Sejalan dengan itu selanjutnya, pemerintah di seluruh dunia mengeluarkan kebijakan terkait social distancing sampai dengan psychal distancing yang pada akhirnya merubah segala aktivitas masyarakat (Oe dan Weeks, 2020). Seperti halnya yang terjadi di Papua, meliputi beragam hal: mulai dari kegiatan sosial, pentas seni, konser musik, tempat perbelanjaan (diluar kebutuhan pokok dan sehari-hari), kafe-restoran, kantor, penutupan bandara, terminal, pelabuhan, pasar, sekolah hingga menjadi sejarah baru yaitu ditutupnya kampus dalam waktu yang mendadak di Kota Jayapura dan serentak di seluruh Papua.

Berdasarkan fakta yang terjadi di Universitas Cenderawasih (Uncen) Papua pada saat pandemi Covid-19 bulan Maret s/d Mei tahun 2020, bahwa secara 
keseluruhan kegiatan akademik dan nonakademik dihentikan untuk waktu yang belum dapat ditentukan. Seluruh civitas akademika Uncen juga sangat terkena dampak dari Covid-19 antara lain: mahasiswa, dosen, tenaga kependidikan, dan pejabat fakultas dan universitas kemudian mengalihkan beban pekerjaannya masing-masing dari rumah.

Disrupsi budaya yang terjadi ini kemudian dikenal dengan istilah WFH (work from home), hal ini didasarkan pada Surat Edaran Nomor 15 Tahun 2020 tentang Pedoman Penyelenggaraan Belajar dari Rumah dalam Masa Darurat Penyebaran Covid-19 yang di terbitkan oleh Kementerian Pendidikan dan Kebudayaan (Kemendikbud) dan Surat Edaran Rektor Uncen Nomor 1423/UN20/KP/2020 tentang Pembatasan dan Pencegahan Penyebaran Corona Virus Disease (Covid19) di Universitas Cenderawasih.

Namun kegiatan WFH inipun bukannya tanpa hambatan, perbedaan fasilitas sarana dan prasarana kelengkapan WFH terutama ketersediaan digital teknologi antara wilayah Indonesia bagian barat dan Timur terasa cukup jauh. Lebih jauh dari pada itu ada hal yang perlu dipahami bersama bahwa ini bukanlah "liburan" kampus yang biasa di kehendaki atau dilakukan di setiap pergantian semester. Segala macam upaya akhirnya ditempuh dalam rangka memastikan bahwa proses mencerdaskan kehidupan anak bangsa harus tetap berjalan.

Oleh karena itu, kombinasi kegiatan belajar mengajar secara tatap muka dan melalui media digital diprediksi akan banyak digunakan. Sebagai akibatnya, kondisi new normal (kenormalan baru) dalam kehidupan kampus tidak hanya akan terjadi pada aspek pembelajaran. Adaptasi sosial moral, intelektual, teknologi menjadi titik penting dari peran serta aktif dunia pendidikan merespon terjadinya perubahan.

Tantangan dapat menjadi peluang apabila situasi ini menjadi pemicu kreativitas dosen sebagai garda terdepan perang melawan penyakit menular berbahaya di tingkat perguruan tinggi (Javaid, dkk, 2020). Sektor daring digital dalam rangka edukasi masyarakat melalui interaksi aktif tenaga pengajar dan mahasiswa tanpa berjumpa langsung namun efektif.

\section{METODE}

Pengabdian yang dilaksanakan menggunakan metode partisipatif (Hasanah, 2016). Teknis kegiatan pengabdian diawali dengan melakukan komunikasi dengan mahasiswa Fakultas Ilmu Keolahragaan (FIK) Uncen dan menyampaikan perihal pendidikan kesehatan menggunakan media daring (onine). Media yang yang digunakan 
adalah aplikasi zoom dan WA, kedua aplikasi tersebut diperoleh dengan cara install melalui play store yang terdapat pada handphone (HP) masing-masing peserta kegiatan (Karman, 2012). Berkaitan dengan adanya beberapa kendala seperti: belum semua mahasiswa memiliki HP tipe android atau smartphone; jaringan internet yang tidak merata dan koneksi tidak selalu baik; dan kemampuan bandwidth yang relatif terbatas.

Oleh karenanya, kemudian dilakukan beberapa langkah-langkah solutif, meliputi: forum interaktif online dibuat berkelompok dengan didampingi pemateri dosen pengabdi; kegiatan lebih banyak dilakukan fleksibel waktu namun dengan target materi; dan materi yang diberikan dengan konsep sederhana dan lebih banyak memberikan kesempatan peserta untuk aktif. Jenis data pengabdian ini adalah bersifat kualitatif, data yang dibuat dengan kalimat ataupun kata-kata. Adapun sumber data diperoleh melalui diskusi tanya jawab, analisis dokumen, dan quiz. Selain itu, data juga diperoleh dalam rekaman video dan juga melalui foto kegiatan.

Pengabdian ini diberikan dalam bentuk sosialisasi yang dilaksanakan pada tanggal 11 s/d 30 Juni 2020, dan diikuti sebanyak 26 peserta. Kegiatan ini menggunakan media daring digital yang dilaksanakan dari rumah/ tempat tinggal pengabdi, dan untuk peserta dilakukan secara berkelompok yakni 3 s/d 4 orang.

Kegiatan evaluasi yang telah dilaksanakan yaitu dengan mengadakan refleksi (feedback dari peseta oleh pengabdi, dan menggali kesan dan pesan dari peserta setelah mengikuti kegiatan pengabdian. Kriteria keberhasilan pelatihan dilihat dari segi pengetahuan (knowledge) dan keaktifan peserta.

\section{HASIL}

Pengabdian pada masyarakat (PPM) yang telah dilaksanakan adalah dalam wujud digital learning health education yang dilaksanakan pada tanggal 11,22, dan 29 Juni 2020 dengan pembiayaan bersumber dari PNBP (penerimaan negara bukan pajak) FIK Uncen tahun anggaran 2020 dengan nomor kontrak: 1729/UN20.3.1 /PM/2020. Peserta dalam kegiatan ini berjumlah 26 orang mahasiswa. Melalui kegiatan ini, juga diberikan informasi terkait beberapa kebijakan yang dilakukan oleh pimpinan FIK Uncen berdasarkan Surat Edaran dari Kemendikbud dan Rektor Uncen tentang pelaksanaan pembelajaran, pencegahan, dan penanggulangan Covid-19, yaitu:

a. Melakukan pembelajaran teori dan praktik laboratorium dengan menggunakan sistem daring (online).

b. Menunda atau membatalkan 
penyelenggaraan kegiatan yang

menimbulkan kerumunan banyak orang dan menunggu informasi perkembangan dari Kementerian Kesehatan.

c. Menyediakan sarana cuci tangan menggunakan air dan hand sanitizer di tempat kerja yang dibutuhkan seperti pintu masuk, ruangan kerja, mesin absensi dan tempat lain yang sering di akses oleh dosen dan tenaga kependidikan (Tendik).

d. Memastikan seluruh area tempat kerja dan lingkungan kampus bersih serta higienis dengan melakukan pembersihan menggunakan disinfektan.

e. Mendata mahasiswa dan pegawai FIK Uncen apabila terdapat tanda gejalagejala Covid-19 untuk segera dirujuk ke fasilitas pelayanan kesehatan.

f. Melakukan penyelenggaraan pelaksanaan tugas kedinasan kepada pegawai dengan bekerja di rumah/tempat tinggal (work form home) dengan ketentuan yang berlaku serta dengan jadwal sistem dan presensi online.

g. Himbauan kepada seluruh pegawai dan mahasiswa FIK Uncen untuk meminimalisir kegiatan diluar rumah dan menghindari kerumunan banyak orang yang tidak memungkinkan dilakukan tindakan kewaspadaan dan pencegahan penularan.

h. Himbauan kepada seluruh civitas akademika (dosen, Tendik dan mahasiswa) FIK Uncen untuk menerapkan perilaku hidup bersih dan sehat (PHBS) dalam aktivitas kehidupan sehari-hari.

Pelaksanaan PPM ini merupakan tugas Tridharma perguruan tinggi, dalam kondisi sedang dalam masa pandemi Wabah Covid19 di Kota Jayapura, kemudian proses belajar mengajar (PBM) yang biasa dilakukan secara tatap muka akhirnya kemudian dialihkan menggunakan metode Pembelajaran pendidikan jarak jauh (PJJ) secara daring (online) demi mencegah dan memutus mata rantai penyebaran Covid-19. Aplikasi digital zoom dan whatsapp dipilih oleh pengabdi dalam kegiatan ini, hal ini juga dilakukan dalam rangka memenuhi tujuan pendidikan dan ikut serta membantu pemerintah. Metode yang dilaksanakan adalah dengan paparan materi dalam bentuk Microsoft power point (ppt), portable document format (pdf) reader adobe systems, video pendek yang ditransfer ke aplikasi yang digunakan.

Kegiatan pengabdian PJJ melalui daring oleh peneliti di kemas menarik dengan beberapa hal yang dilakukan untuk mengajak mahasiswa untuk berdiskusi online dengan membagikan video kasus yang sesuai dengan topik terkini, dimana melatih kemampuan kognitif mahasiswa untuk menganalisis dan interpretasi dalam 
bentuk argumen atau pendapat masingmasing. Respon mahasiswa dengan adanya kegiatan ini adalah antusias dan menyambut dengan baik serta memberikan suasana lebih open mind, and open heart.

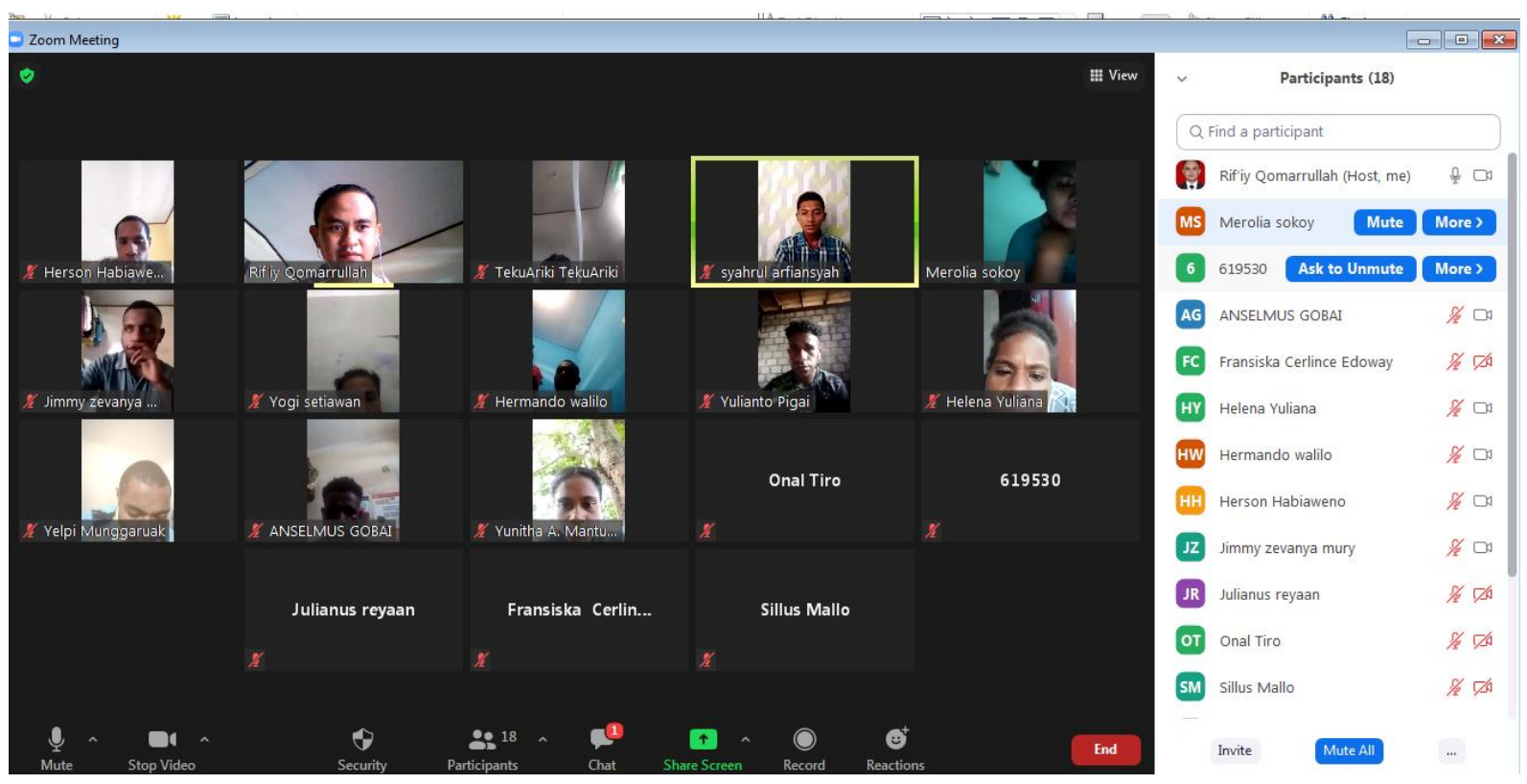

Gambar 1. Kegiatan Implementasi Zoom Meeting untuk pembelajaran

Media daring digital ini juga menjadi sebagai ajang forum diskusi dimana pengabdi juga memberikan kuis atau game sederhana yang memancing penasaran mahasiswa untuk lebih ingin tahu, selain itu juga banyak hal lain lagi yang dilakukan melalui daring ini sehingga menjadi menarik, dan ilmu yang di sampaikan dapat di pahami oleh mahasiswa walaupun dengan kondisi terbatas dan tidak di lakukan tatap muka langsung dengan tanpa mengurangi rasa interaksi secara emosional antara dosen dan mahasiswa.

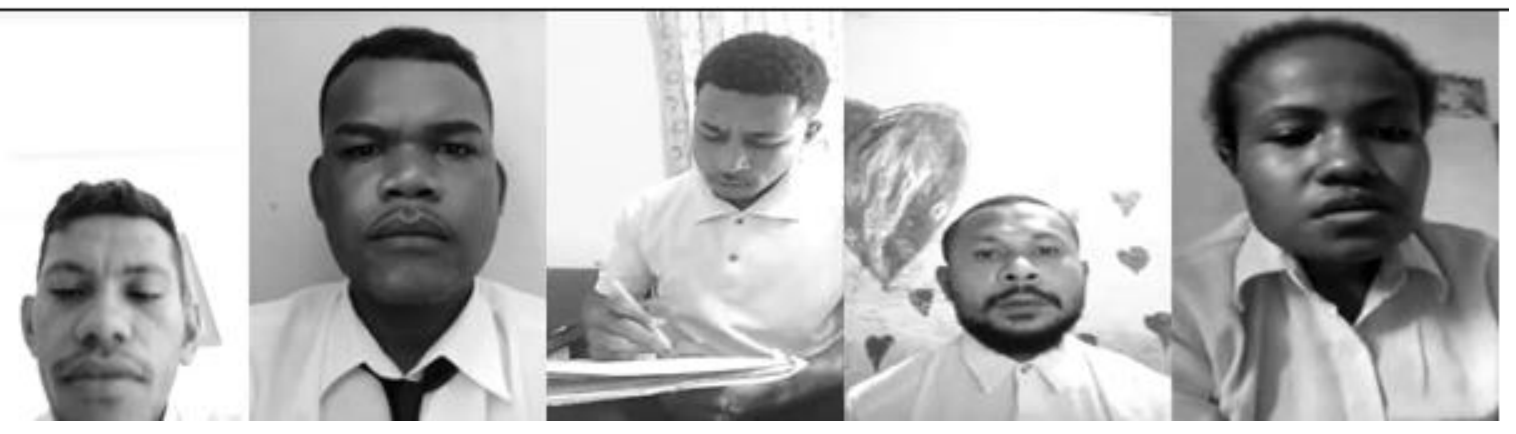

Gambar 2. Kegiatan Implementasi Materi Via Aplikasi Whatsapp 


\section{PEMBAHASAN}

Pendidikan tinggi dan sumber daya manusia (SDM) di Indonesia memiliki keterkaitan yang tidak dapat dipisahkan dengan proses dalam pendidikan. Proses pendidikan merupakan suatu aktivitas untuk menciptakan SDM yang cakap, terampil, dan kompeten (Julinar dan Yusuf, 2019). Kemudian, hingga saat ini SDM dan teknologi adalah faktor utama pelaksana pembelajaran jarak jauh (PJJ) dalam masa pandemi di setiap institusi (Taufik, 2019). Faktor lain dari terus bergeraknya roda pendidikan adalah kreativitas dan keyakinan bahwa disrupsi teknologi menjadi sahabat kehidupan manusia sekarang ini.

Pelaksanaan PPM adalah kegiatan civitas akademika yang memanfaatkan ilmu pengetahuan dan teknologi untuk memajukan kesejahteraan masyarakat dan mencerdaskan kehidupan bangsa. Pembelajaran secara daring digital dianggap menjadi solusi tetap berjalannya KBM pada masa pandemi Covid-19. Pembelajaran berbasis media digital merupakan model pembelajaran yang memanfaatkan fasilitas teknologi informasi komunikasi (TIK). Model semacam ini merupakan bagian dari PJJ yang menggunakan teknologi komputer, HP, dan internet. Teknologi aplikasi zoom dan whatsapp memungkinkan sistem transfer materi pengetahuan disalurkan melalui koneksi internet maupun dari tempat peserta didik tanpa harus melakukan tatap muka dengan dosen di dalam kelas. Adapun manfaat yang didapat dari kegiatan ini yakni bahwa dalam situasi apapun jika ada kemauan pasti ada jalan. Ternyata melakukan kegiatan PPM secara daring tetap bisa dijalankan, walaupun ada beberapa kendala, diantaranya keterbatasan waktu dalam penggunaan aplikasi zoom meeting dan juga tidak semua siswa memiliki laptop/HP android. Sehingga beberapa siswa hanya mendengarkan saja dari handphone temannya. Kemudian, hal tersebut dapat dipahami dan dicerna dengan baik oleh peserta bahwa promosi kesehatan juga perlu mendapatkan perhatian. Selanjutnya, perilaku hidup bersih sehat (PHBS) guna mewujudkan masyarakat Papua yang peduli sehat sudah terlaksana dan dapat diterima dengan baik oleh mahasiswa. Mahasiswa sangat antusias dengan kegiatan ini. Program semacam ini sangat penting dilakukan terutama pada mahasiswa sebagai anggota masyarakat untuk menyadarkan pentingnya mengupayakan perilaku hidup bersih sehat. Selanjutnya, untuk masa yang akan datang depan praktik yang disosialisasikan dan diterapkan dalam kehidupan sehari hari masyarakat secara kontinyu. 


\section{SIMPULAN}

Simpulan dari kegiatan PPM ini yaitu bahwa pelaksanaan belajar jarak jauh telah menjadi sebuah kebutuhan, dan teknologi memainkan peran penting. Covid19 adalah wabah pandemi yang harus terus di informasikan kepada masyarakat, khususnya mahasiswa. Perilaku hidup sehat dan bersih berikutnya adalah sesuatu yang mutlak diaksanakan pada masa kenormalan baru.

\section{SARAN}

Saran yang dapat diberikan dari kegiatan ini yakni: masyarkat harus taat protokol kesehatan dan memiliki kesadaran, dan kemauan; hidup dalam lingkungan PHBS; dan masyarakat hendaknya benarbenar memanfaatkan teknologi agar terhindar serta mencegah penyebaran penyakit berbahaya seperti Covid-19.

Selain itu, perlu adanya standar yang disusun oleh Uncen terkait dengan PJJ atau pembelajaran daring. Lebih lanjut, mediamedia pembelajaran daring dapat digunakan seterusnya terlebih berkaitan dengan program Merdeka Belajar Kampus Merdeka.

\section{UCAPAN TERIMA KASIH}

Terima kasih disampaikan kepada segenap pimpinan FIK Uncen, dan mahasiswa yang telah memberikan dukungan kegiatan pengabdian ini.

\section{DAFTAR PUSTAKA}

Arifin, Miftah. Nahar, Aida. (2017). Pengembangan Sistem Administrasi Sekolah Berbasis Teknologi Informasi di MTS. Darul Ulum dan MTS. Miftahul Huda di Kabupaten Jepara. Journal of Dedicators Community, 1(1), 47-56.

Dimyati A, Mohamad. Suwardiyanto, Devit. Yuliandoko, Herman. Arief W., Vivien. (2017). Pemanfaatan Teknologi Sebagai Media Pembelajaran Daring (Online) Bagi Guru dan Siswa di SMK NU Rogojampi. Jurnal J-DINAMIKA, 2(2), 96-100.

Hasanah, Hasyim. (2016). Teknik-Teknik Observasi (Sebuah Alternatif Metode Pengumpulan Data Kualitatif Ilmuilmu Sosial). Jurnal at-Taqaddum, 8(1), 21-46.

Javaid, Mohd. Haleem, Abid. Vaishya, Raju. Bahl, Shashi. Suman, Rajiv. Vaish, Abhishek. (2020). Industry 4.0 Technologies and Their Applications in Fighting COVID-19 Pandemic. Diabetes \& Metabolic Syndrome: Clinical Research \& Reviews, 14(2), 419-422.

Juliannisa, Indri Arrafi. (2020). Peningkatan Pembelajaran Melalui Situs Media 
Online dengan Metode Blended

Learning pada Masyarakat Desa

Bojongcae. Journal of Dedicators

Community, 4(1), 68-78.

Julinar. Yusuf, Nur. (2019). Flipped Learning Model: Satu Cara Alternatif untuk Meningkatkan Keterampilan Berbicara Siswa. Jurnal Penelitian Pendidikan, 19(3), 366-373.

Karman. (2012). Pola Penggunaan Media Digital di Kalangan Anak dan Remaja (Kasus di Kota Jayapura Provinsi Papua). Jurnal Penelitian Pos dan Informatika, 2(1), 35-50.

Lau, Hien. Khosrawipour, Veria. Kobach, Piotr. Mikolajczyk, Agata. Schubert, Justyna. Bania, Jacek. Khosrawipour, Tanja. (2020). The Positive Impact of Lockdown in Wuhan on Containing The COVID-19 Outbreak in China. Journal of Travel Medicine, 27 (3), 17.

Oe, Hiroko. Weeks, Max. (2020). How to Support Vulnerable Citizens during the COVID-19 Lockdown: A Community Initiative from Ubiquitous Network Perspectives. Budapest International Research and Critics Institute, 3(2), 1369-1377.

Pratiwi, Umi. Nurhidayati. (2017).

Penerapan Sains Teknologi Masyarakat (STM) untuk Peningkatkan Kemampuan Pedagogik
Guru dan Calon Guru PAUD Kec. Panjer Kab. Kebumen. Journal of Dedicators Community, 1(1), 82-92. Taufik, Ali. (2019). Perspektif Tentang Perkembangan Sistem Pembelajaran Jarak Jauh di Kabupaten Kutai Kartanegara Kalimantan Timur. Jurnal Pendidikan: Riset dan Konseptual, 3(2), 88-98.

Yuliana, Y. 2020. "Corona Virus Diseases (Covid-19): Sebuah Tinjauan Literatur". Wellness and Healthy Magazine, 2(1), 187-192.

Yunus, Nur Rohim. Rezki, Annissa. 2020. "Kebijakan Pemberlakuan Lock Down Sebagai Antisipasi Penyebaran Corona Virus Covid-19". Salam: Jurnal Sosial dan Budaya Syar'i, 7(3), 227-238. 